\title{
Peningkatan Prestasi Belajar dan Keaktifan Siswa Kelas XI MIPA-3 SMA Negeri 3 Cilacap melalui Model Discovery Learning Berbantuan Media Inovatif dan Software Pesona Fisika Materi Teori Kinetik Gas Tahun 2015/2016
}

\author{
Salpan $^{\text {a) }}$ \\ SMA Negeri 3 Cilacap \\ Email: a)salpanabror@gmail.com
}

\begin{abstract}
This study aims to describe the improvement of learning achievement and student activeness of class XI MIPA-3 SMA Negeri 3 Cilacap through innovative media-assisted discovery learning model and physics charm software on kinetic gas theory material of 2015/2016. The subject of the research is the students of class XI MIPA-3 even semester SMA Negeri 3 Cilacap Year 2015/2016. The study was conducted in two cycles. Data collection using written tests, observation sheets and peer ratings sheets. Data analysis was done by descriptive analysis percentage. Indicators of achievement of learning achievement above $75 \%$ and student activeness $60 \%$ high and $40 \%$ moderate. The result of the research shows that (1) description of the improvement of learning achievement with innovative media-assisted discovery learning model and physics charm can improve learning achievement from the average of 72,12 to 74,29 and $70,59 \%$ to $70,47 \%$ (2) description of student's activeness improvement with innovative media-assisted discovery learning model and physics charm can increase students' activity from $58,82 \%$ high to $61,76 \%$.
\end{abstract}

Keywords: Disvovery Learning, Innovative Media, Enchantment Physics.

\begin{abstract}
Abstrak
Penelitian ini bertujuan untuk mendeskripsikan peningkatan prestasi belajar dan keaktifan siswa kelas XI MIPA-3 SMA Negeri 3 Cilacap melalui model discovery learning berbantuan media inovatif dan software pesona fisika pada materi teori kinetik gas tahun 2015/2016. Subjek penelitian adalah siswa kelas XI MIPA-3 semester genap SMA Negeri 3 Cilacap Tahun 2015/2016. Penelitian dilakukan dalam dua siklus. Pengumpulan data menggunakan tes tertulis, lembar observasi dan lembar penilaian teman. Analisis data dilakukan dengan analisis deskriptif persentase. Indikator keberhasilan prestasi belajar di atas $75 \%$ dan keaktifan siswa $60 \%$ tinggi dan $40 \%$ sedang. Hasil penelitian menunjukkan bahwa, (1) deskripsi peningkatan prestasi belajar dengan model discovery learning berbantuan media inovatif dan pesona fisika dapat meningkatkan prestasi belajar dari rata-rata nilai sebesar 72,12 menjadi 74,29 dan ketuntasan belajar 70,59\% menjadi 76.47\%, (2) deskripsi peningkatan keaktifan siswa dengan model discovery learning berbantuan media inovatif dan pesona fisika dapat meningkatkan keaktifan siswa dari 58,82\% tinggi menjadi $61,76 \%$.
\end{abstract}

Kata-kata Kunci: Disvovery Learning, Media Inovatif, Pesona Fisika. 


\section{PENDAHULUAN}

Sesuai dengan Kurikulum 2013, bahwa penempatan siswa pada program studi dimulai dari kelas $\mathrm{X}$ berdasarkan nilai murni hasil ujian nasional SMP dan nilai tes peminatan siswa. Namun demikian pada peminatan MIPA masih terdapat siswa yang belum bisa mengikuti pembelajaran dengan baik. Sehingga siswa tersebut tidak dapat bersaing dengan siswa lain yang memang benar-benar layak di peminatan MIPA. Meskipun mereka memilih peminatan MIPA, namun kenyataannya sampai saai ini masih ada siswa yang berangganpan bahwa fisika merupakan mata pelajaran yang sulit dan menjemukan. Salah satu alasannya adalah bahwa mata pelajaran fisika banyak memuat rumus-rumus matematis. Alasan lain diantaranya adalah proses pembelajaran yang kurang menyenangkan.

Konsep-konsep abstrak dalam fisika yang mestinya dikonkritkan dengan media pembelajaran, namun dalam pembelajaran masih jarang memanfaatkan media yang ada. Akibatnya siswa kurang termotivasi dan aktif dalam mengikuti pembelajaran sehihgga berdampak pada hasil belajar yang kurang memuaskan. Hasil belajar fisika kelas XI aspek kognitif ditunjukkan pada TABEL 1 berikut ini.

TABEL 1. Rekapitulasi Prestasi Belajar Siswa Sebelum Tindakan

\begin{tabular}{cccccc}
\hline \multirow{2}{*}{ No. } & \multirow{2}{*}{ Kelas } & \multicolumn{3}{c}{ Nilai US Sem-1 } & \multicolumn{2}{c}{ Nilai UH 1 Sem-2 } \\
\cline { 3 - 6 } & & Rata $^{2}$ & Ketuntasan & Rata $^{2}$ & Ketuntasan \\
\hline 1 & XI IPA-1 & 71,29 & $72 \%$ & 71,12 & $71 \%$ \\
2 & XI IPA-2 & 70,43 & $67 \%$ & 72,23 & $70 \%$ \\
3 & XI MIPA-3 & 68,62 & $55 \%$ & 67,71 & $58 \%$ \\
4 & XI IPA-4 & 72,72 & $73 \%$ & 75,37 & $74 \%$ \\
\hline
\end{tabular}

Sumber: Daftar Nilai Salpan Semester I dan II T.P. 2015/2016

TABEL 1 menunjukkan bahwa di antara keempat kelas program MIPA, kelas XI MIPA-3 merupakan kelas yang nilai rata-ratanya paling rendah dan ketuntasannya paling sedikit. Selain prestasi belajar yang belum memuaskan, berdasarkan pengamatan dan penuturan guru-guru lian bahwa keaktifan siswa dalam mengikuti pembelajaran juga masih rendah.

Uraian tersebut mendorong penulis untuk berinovasi dan mengadakan penelitian tindakan kelas dengan permasalahan: (1) Bagaimana peningkatan prestasi belajar siswa kelas XI MIPA-3 SMA Negeri 3 Cilacap melalui model discovery learning berbantuan media inovatif dan software pesona fisika materi teori kinetik gas tahun 2015/2016, (2) Bagaimana peningkatan keaktifan kelas XI MIPA-3 SMA Negeri 3 Cilacap melalui model discovery learning berbantuan media inovatif dan software pesona fisika materi teroi kinetik gas tahun 2015/2016?

Tujuan dari penelitian ini adalah: (1) mendeskripsikan peningkatan prestasi belajar siswa kelas XI MIPA-3 SMA Negeri 3 Cilacap melalui model discovery learning berbantuan media inovatif dan software pesona fisika materi teori kinetik gas tahun 2015/2016, (2) mendeskripsikan peningkatan keaktifan siswa kelas XI MIPA-3 SMA Negeri 3 Cilacap melalui model discovery learning berbantuan media inovatif dan software pesona fisika materi teori kinetik gas tahun 2015/2016.

Manfaat penelitian ini adalah (1) meningkatkan prestasi belajar siswa, (2) meningkatkan keaktifan belajar siswa, (3) memberikan motivasi kepada guru-guru fisika untuk berinovasi dalam pembelajaran fisika serta menggunakan media secara optimal.

Hilgard berpendapat bahwa: "learning is the process by which an activity ariginates or changed through training procedures (wether in the laboratory or in the natural environment) as distinguished from by factors not atributable to training". Belajar adalah proses perubahan tingkah laku melalui kegiatan atau prosedur latihan baik di dalam laboratorium maupun dalam lingkungan alamiah sehingga terjadi proses perubahan mental pada individu (Sanjaya, 2008:228).

Belajar dan mengajar merupakan proses yang tidak dapat dipisahkan sebagai satu kesatuan yang utuh antara siswa dengan pendidik. Kegiatan belajar dan mengajar yang berlangsung secara bersamaan sering pula disebut sebagai kegiatan pembelajaran. Pandangan mengenai pembelajaran, Isjono (2010:14) berpendapat bahwa pembelajaran adalah sesuatu yang dilakukan oleh siswa, bukan dibuat untuk siswa. Pembelajaran pada dasarnya merupakan upaya pendidik untuk membantu siswa melakukan kegiatan belajar.

Media pembelajaran adalah sesuatu yang dapat digunakan untuk menyalurkanspesan dalam pembelajaran, sehingga dapat merangksang perhatian, minat, pikiran, dan perasaan siswa dalam 
kegiatan belajar untuk mencapai tujuan belajar. Media pembelajaran merupakan komponen integral dari sistem pembelajaran. Susilana dan Riyana (2007:7-8) berpendapat bahwa media pembelajaran mempunyai kegunaan (1) memperjelas pesan agar tidak terlalu verbalistis, (2) mengatasi keterbatasan ruang, waktu, (3) menumbuhkan semangat belajar siswa, (4) memungkinkan anak belajar mandiri, (5) memberikan rangsangan kepada siswa, (6) membuat konkrit konsep-konsep yang abstrak, (7) menghadirkan objek-obek yang terlalu berbahaya atau sukar di dapat ke dalam lingkungan belajar.

Media pembelajaran dapat berupa media rril dan media virtuil. Media virtuil merupakan media interaktif berbasis komputer. Media interaktif menurut Anitah (2008:8) dijelaskan bahwa media interaktif dipandang sebagai media yang efektif dan dapat memotivasi untuk mempelajari sains.

Dalam Kamus Besar Bahasa Indonesia (2002:895) prestasi diartikan sebagai hasil yang telah dicapai dari apa yang telah dilakukan atau dikerjakan. Jadi prestasi belajar dapat diartikan sebagi hasil yang telah dicapai melalui penguasaan pengetahuan atau ketrampilan yang dikembangkan melalui mata pelajaran. Prestasi belajar lazimnya ditunjukkan dengan nilai tes atau angka nilai yang diberikan guru. Pandangan lain dikemukakan oleh Sudjana (2010:22), yang menyatakan bahwa hasil belajar merupakan kemampuan-kemampuan yang dimiliki siswa setelah ia menerima pengalaman belajarnya.

Kegiatan pembelajaran dapat berlangsung dengan dicerminkan oleh adanya aktivitas siswa. Menurut Widodo sebagaimana yang dikutip Fitri Megasari (2014) menyebutkan bahwa interaksi belajar-mengajar merupakan aktivitas prinsip yang sangat penting dalam pembelajaran.

Dalam lampiran Permendikbud Nomor 103 Tahun 2014 tentang Pembelajaran pada Pendidikan Dasar dan Menengah disebutkan bahwa, model pembelajaran merupakan suatu bentuk pembelajaran yang memiliki nama, ciri, sintak, pengaturan, dan budaya misalnya discovery learning, project-based learning, problem-based learning, inquiry learning. Model discovery learning merupakan model pembelajaran yang memberikan kesempatan kepada siswa untuk mencari tahu tentang suatu permasalahan dan menemukan solusinya berdasarkan kepada hasil pengolahan informasi yang dicari dan dikumpulkannya sendiri.

Beberapa penelitian sebelumnya yang terkait dengan penelitian ini antara lain penelitian yang dilakukan oleh (1) Destrika Kumalasari, dkk (2013), menunjukkan bahwa model discovery learning berpengaruh positif terhadap keterampilan proses sains dan hasil belajar siswa, (2) Vivien Dwi Indriyani (2014), menunjukkan bahwa model pembelajaran discovery learning dapat diterapkan untuk meningkatkan prestasi belajar dan kemampuan kerja ilmiah siswa, (3) Putri Alifatul Rakhmadani (2014), menyimpulkan bahwa model discovery learning disertai media audiovisual berpengaruh yang signifikan terhadap hasil belajar IPA siswa, (4) Amalia Atmaja Putri (2015), menyimpulkan bahwa aktivitas belajar dan hasil belajar fisika siswa menggunakan model discovery laerning disertai metode aksperimen mengalami peningkatan dibandingkan sebelum tindakan, (5) Fitri Megasari (2014), hasilnya menunjukkan bahwa penerapan model discovery laerning dapat meningkatkan aktivitas dan hasil belajar siswa.

Penelitian ini diawali dari permasalahan prestasi belajar siswa yang rendah. Hal ini ditunjukkan oleh adanya siswa yang tuntas belajar masih di bawah $70 \%$. Di samping prestasi siswa yang rendah, keaktifan siswa juga masih dalam kategori kurang. Salah satu cara untuk mengatasi permasalah tersebut adalah dengan menerapkan model disvory learning berbantuan media inovatif dan software pesona fisika. Pemberlajaran ini berpusat pada siswa, sehingga siswa harus terlibat langsung untuk melakukan.

Sesuai dengan karakteristik mata pelajaran Fisika yang menuntut adanya observasi dan eksperimen, maka media pembelajaran merupakan sarana pembelajaran yang mutlak diperlukan. Media riil maupun media interaktif berbasis komputer merupakan media pembelajaran yang dapat menciptkan suasana pembelajaran yang efektif dan menyenangkan. Sehingga hasil akhir dari penerapan model ini adalah prestasi belajar dan keaktifan siswa meningkat. 


\section{METODE PENELITIAN}

Penelitian ini dilaksanakan mulai bulan April sampai dengan September 2016 dengan subjek penelitian siswa kelas XI MMIPA-3 SMA Negeri 3 Cilacap Tahun Pelajaran 2015/2016. Penelitian dilakukan melalui tahapan studi pendahuluan dan tindakan dalam dua siklus. Setiap tindakan dilakukan melalui tahapan perencanaan, pelaksanaan tindakan, observasi, dan refleksi. Setiap Penelitian tindakan ini dilakukan melalui dua siklus.

Instrumen penelitian berupa soal ulangan untuk mengumpulkan data prestasi belajar, lembar pengamatan dan lembar penilaian teman sejawat untuk mengumpulkan data keaktifan siswa. Data prestasi belajar siswa dianalisis dengan teknik analisis persentase untuk mengetahui jumlah siswa yang tuntas belajar. Siswa dikatakan tuntas belajar jika nilainya telah mencapai 70 . Ketuntasan secara klasikal jika jumlah siswa yang nilainya mencapai KKM lebih dari $75 \%$ dari jumlah siswa dalam satu kelas.

Persentase ketuntasan klasikal $=\left(\frac{n}{N}\right) \times 100 \%$

Data keaktifan siswa merupakan data kualitatif yang diubah menjadi data kuantitif dengan cara memberikan skor 1, 2, 3, 4 kemudian dikonversi menjadi nilai skala 0-100. Data akhir merupakan rata-rata dari data hasil penilaian teman sejawat dan data rata-rata hasil observasi. Data dianalisis dengan menggunakan analisis deskriptif sederhana, yakni dengan menggolongkan rentang nilai 0-19 kategori sangat rendah, 20-49 rendah, 50-79 sedang dan 80-100 tinggi dengan bantuan program excel.

\section{HASIL DAN PEMBAHASAN}

\section{Deskripsi Data}

Berdasarkan temuan pada kondsi awal sebagaimana ditunjukkan pada TABEL 1, bahwa prestasi belajar siswa kelas XI MMIPA-3 masih rendah yang ditunjukkan oleh adanya ketuntasan secara klasikal masih di bawah 70\%. Hasil tindakan ditunjukkan pada tabel berikut.

TABEL 2. Rekapitulasi Data Prestasi Belajar Siswa

\begin{tabular}{lcccl}
\hline \multirow{2}{*}{ Tindakan } & Rata-rata & \multicolumn{3}{c}{ Ketercapaian } \\
\cline { 3 - 5 } & Nilai & Jumlah Persentase & Keterangan \\
\hline \multirow{2}{*}{ Siklus I } & \multirow{2}{*}{$72, \mathrm{I} 2$} & 24 & 70.59 & Tuntas \\
& & I0 & 29.41 & Tidak Tuntas \\
\multirow{2}{*}{ Siklus II } & 74,29 & 26 & 76.47 & Tuntas \\
& & 8 & 23.53 & Tidak Tuntas \\
\hline
\end{tabular}

\section{Deskripsi Data Keaktifan Siswa}

TABEL 3. Rangkuman Data Keaktifan Siswa

\begin{tabular}{cccc}
\hline Tindakan & Intrval & Kategori & Persentase \\
\hline \multirow{4}{*}{ Siklus I } & $80-$ I00 & Tinggi & 58.82 \\
& $50-79$ & Sedang & 41.18 \\
& $20-49$ & Rendah & 0.00 \\
& $0-19$ & Sangat Rendah & 0.00 \\
\hline \multirow{4}{*}{ Siklus II } & $80-$ I00 & Tinggi & 61.76 \\
& $50-79$ & Sedang & 38.24 \\
& $20-49$ & Rendah & 0.00 \\
& $0-19$ & Sangat Rendah & 0.00 \\
\hline
\end{tabular}

\section{Deskripsi peningkatan prestasi belajar siswa}

Hasil tindakan pada siklus I seperti yang secara ringkas dimuat pada TABEL 2 menunjukkan bahwa prestasi belajar yang dicapai siswa memiliki nilai tertinggi 72,12 dengan jumlah siswa tuntas 
belajar sebesar 70,59\% dan siswa yang nilainya belum tuntas sebesar $29,41 \%$. Angka tersebut belum menunjukkan ketercapaian yang ditargetkan, karena jumlah siswa dinyatakan tuntas masih di bawah $75 \%$. Sedangkan pada siklus II, prestasi belajar siswa diperoleh nilai rata-ratanya 74,29 dengan jumlah siswa yang tuntas belajar sebesar 76,47 \% dan yang tidak tuntas $23,53 \%$. Berdasarkan nilai rata-rata, prestasi belajar siswa dari siklus I ke siklus II mengalami kenaikan sebesar 2,17. Namun jika ditinjau berdasarkan ketuntasannya, prestasi belajar siswa dari siklus I ke siklus II mengalami kanaikan sebesar 5,88 \%.

Hal ini sejalan dengan pemikiran Indriati (2014) yang berpendapat bahwa model pembelajaran discovery learning memiliki kelebihan dapat membantu siswa untuk memperbaiki dan meningkatkan keterampilan-keterampilan dan proses-proses kognitif serta dapat meningkatkan kemampuan siswa untuk memecahkan masalah. Selain itu juga sesuai dengan hasil penelitian yang telah dilakukan oleh: (1) Destrika Kumalasari, bahwa model discovery learning berpengaruh positif terhadap keterampilan proses sains dan hasil belajar siswa pada mata pelajaran Fisika, (2) Putri Alifatul Rakhmadani, bahwa model discovery learning disertai media audiovisual berpengaruh yang signifikan terhadap hasil belajar siswa, (3) Indarti, bahwa kemampuan memecahkan masalah siswa yang pembelajarannya menggunakan model discovery learning lebih baik dari pada kemampuan memecahkan masalah siswa yang pembelajarannya menggunkan model pembelajaran konvensional, (4) Amalia Atmaja Puteri, bahwa aktivitas belajar dan hasil belajar fisika siswa kelas menggunakan model discovery learning disertai metode eksperimen telah mengalami peningkatan dibandingkan sebelum tindakan.

\section{Deskripsi peningkatan keaktifan siswa}

Berdasarkan pengamatan yang dilakukan pada siklus I seperti pada TABEL 3, menunjukkan bahwa keaktifan siswa pada kategori tinggi 58,82 \% dan kategori sedang 41,18\%. Sedangkan pada siklus II, keaktifan belajar siswa mengalami peningkatan, yakni kategori tinggi menjadi $61,76 \%$ dan kategori sedang mejadi 38,24 \%. Dengan demikian dari siklus I ke siklus II, keaktifan belajar siswa pada kategori tinggi mengalami kanaikan sebesar 2,94\% dan pada kategori sedang mengalami penurunan sebesar 2,94\%. Kenaikan kategori tinggi dan penurunan kategori sedang diperoleh angka yang sama karena tidak ada perubahan keaktifan belajar siswa pada kategori rendah dan sangat rendah.

Hal ini sejalan dengan pemikian Bruner dalam Sardiman (2005) yang menyatakan bahwa model pembelajaran discovery learning memberikan kesempatan kepada siswa untuk belajar secara aktif sehingga dapat merubah kegiatan belajar mengajar yang teacher oriented menjadi student oriented. Selain itu juga sesuai dengan hasil penelitian-penelitian sebelumnya yang dilakukan oleh: (1) Vivien Dwi Indriyani, model pembelajaran discovery learning dapat diterapkan untuk meningkatkan prestasi belajar dan kemampuan kerja ilmiah siswa, (2) Amalia Atmaja Puteri, bahwa aktivitas belajar dan hasil belajar fisika siswa menggunakan model discovery learning disertai metode eksperimen telah mengalami peningkatan dibandinkan sebelum tindakan, (3) Fitri Megasari, dkk, bahwa penerapan model pembelajaran discovery learning dapat meningkatkan aktivitas dan hasil belajar siswa pada materi gerak.

\section{SIMPULAN}

Berdasarkan analisis data dan kerangka toeri, dapat disimpulkan bahwa (1) Peningkatan prestasi belajar siswa kelas XI MIPA-3 SMA Negeri 3 Cilacap dapat dilakukan melalui model discovery learning berbantuan media inovatif dan software pesona fisika materi Teori Kinetik Gas tahun 2015/2016. Peningkatan tersebut ditunjukkan dengan adanya kenaikan rata-rata nilai pada siklus I ke siklus II sebesar 2,17. dan kenaikan ketuntasan belajar 5,88\%. (2) Peningkatan keaktifan siswa kelas XI MIPA-3 SMA Negeri 3 Cilacap dapat dilakukan melalui model discovery learning berbantuan media inovatif dan software pesona fisika materi Teori Kinetik Gas tahun 2015/2016. Peningkatan tersebut ditunjukkan dengan adanya kenaikan keaktifan siswa pada siklus I ke siklus II sebesar 2,94\%. Untuk mencapai hasil penelitian yang lebih baik, penulis menyarankan (1) Pembelajaran fisika dengan model discovery learning dengan bantuan media inovatif akan lebih efektif jika semua media dibuat bersama-sama siswa, (2) Pembagian kelompok akan efektif jika siswa berpasangan dalam menggunakan alat peraga. 


\section{REFERENSI}

Amalia Atmaja Putri.2015. Peningkatan Aktivitas dan Hasil Belajar Fisika dengan Model Discovery Learning disertai Metode Eksperimen pada Siswa Kelas X IPA-2 SMA Muhammadiyah 3 Jember Tahun Pelajaran 2014-2015 (Pokok Bahasan: Fluida Statis). Jurnal PTK. Diunduh Tanggal 14 September 2016.

Anitah, S., Media Pembelajaran, Solo, UNS Press, 2008

Indarti, Suyudi, A., Chusnana, I.Y., Pengaruh Model Discovery Learning Terhadap Kemampuan Memecahkan Masalah Siswa Kelas X Sman 8. Malang Universitas Negeri Malang. Diunduh tanggal 14 September 2016

Indriyani, V.D., Muhardjito, Parno. 2014. Penerapan Model Pembelajaran Discovery Learning untuk Meningkatkan Prestasi Belajar dan Kemampuan Kerja Ilmiah Mata PelajarJurusan Fisika Siswa Kelas X Multimedia 1 SMK Muhammdiyah 1 Pasuruhan. Penelitian Tindakan Kelas. FMIPA Universitas Negeri Malang. Jurnal PTK. Diunduh tanggal 14 September 2016.

Isjono, Pembelajaran Kooperatif Meningkatkan Kecerdasan Komunikasi Antar Peserta Didik. Yogyakarta, 2010.

Kumalasari, D., Sudarti, Lesmono, D., Dampak Hasil Belajar Ipa-Fisika Siswa Di MTs Negeri 1 Jember. Pendidikan Fisika, 2013. Jurnal PTK, Diunduh tangal 14 September 2016.

Megasari, D., Penerapan Model Pembelajaran Discovery Learning dalam Upaya Meningkatkan Aktivitas dan Hasil Belajar Fisika Siswa Kelas X MIA 5 SMA Negeri 1 Muaro Jambi, 2014 Artikel ilmiah. Diunduh tanggal 14 September 2014.

Permendikbud Nomor 103 Tahun 2014 tentang Pembelajaran pada Pendidikan Dasar dan Menengah

Poerwadarminta, WJS., Kamus Besar Bahasa Indonesia. Jakarta, Balai Pustaka, 2001.

Putri, A.A., Peningkatan Aktivitas dan Hasil Belajar Fisika dengan Model Discovery Learning disertai Metode Eksperimen pada Siswa Kelas X IPA-2 SMA Muhammadiyah 3 Jember Tahun Pelajaran 2014-2015 (Pokok Bahasan: Fluida Statis), 2015, Jurnal PTK, Diunduh Tanggal 14 September 2016.

Sanjaya, W., Strategi Pembelajaran Berorientasi Standar Proses Pendidikan, Jakarta, Prenada Media Group, 2006.

Sudjana, Penilaian Hasil Proses Belajar Mengajar. Bandung, PT. Remaja Rosdakarya, 2010.

Susilana, R., dan Riyana, C., Media Pembelajaran. Bandung, CV Wacana Prima, 2007. 